\title{
Flood risk mitigation and anthropogenic modifications of a coastal plain in southern Italy: combined effects over the past 150 years
}

\author{
O. Petrucci ${ }^{1}$ and M. Polemio ${ }^{2}$ \\ ${ }^{1}$ CNR-IRPI, Via Cavour 4/6, 87030 Rende (Cosenza), Italy \\ ${ }^{2}$ CNR-IRPI,Via Amendola 122/I, 70126 Bari, Italy
}

Received: 10 October 2006 - Revised: 25 January 2007 - Accepted: 21 May 2007 - Published: 4 June 2007

\begin{abstract}
A study of the effects of human modification of a coastal plain mainly involving land reclamation and flood protection is proposed. The approach involves historical, geomorphological and hydrological data as a whole, taking into account the equilibrium of rivers, plains and coastal areas.

The test area, a telling example of profound economic and social transformation of a coastal plain, is the Piana di Sibari (Calabria, southern Italy), subject to major human modifications over the last 150 years. The study area, at most $300 \mathrm{~m}$ a.s.l., is $450 \mathrm{~km}^{2}$ wide and comprises 24 hydrographic basins.

The approach is based on the creation and analysis of four databases: 1) a historical series of geo-coded flood damage (DAMAGES database), concerning damaging floods which occurred over the past few centuries in the study area; 2) a geocoded series of protection works for land reclamation, protection from floods and improvement of soil stability in steep areas (WORKS database), gathered from the archives of the agencies that carried out the works, organized in a GISformat; 3) a historical series of maximum flood discharges and extreme rainy events (HYMAX database) aimed at defining the trends of occurrence and the intensity of flooding; 4) a coastal line position and migration over time (COASTAL database), created using mainly literature data based on discontinuous data such as historical maps and images.

The work describes the complex succession of floods, protection and reclamation works, human transformation of the plain and major land use changes over the last two centuries in the test area. The new characteristics of the plain and its modifications, including major engineering works, land-use transformation and urbanisation, are illustrated. The damaging floods of the last 200 years, the modifications of runoff and flooding due to works built over the basins, hydrological data and the records concerning coastal modifications were
\end{abstract}

Correspondence to: O. Petrucci

(o.petrucci@irpi.cnr.it) used to create specific databases and a GIS in which these data can be analyzed by typology, location and extension.

The proposed approach highlights the high degree of correlation between drainage basin management, mainly in terms of increasing protection from natural hazards, and anthropogenic development in a broad coastal plain.

\section{Introduction}

The purely natural system ruled the environment in the past; many natural events such as earthquakes, volcanic eruptions, landslides and/or floods became natural disasters only after the appearance of Homo sapiens (Alcantara-Ayala, 2002).

Anthropogenic modifications carried out to cope with natural disasters, generally improve the characteristics of the environment from the human point of view. However, while some kinds of works have a negligible effect on the environment, others have a major impact.

Nowadays, in some areas of the world, the damage due to natural disasters is much greater than before. Significant examples can be observed in Italy (CNR-GNDCI, 1995), where Alpine and Apennine mountainous and hilly areas were highly urbanised for many centuries up to the beginning of the industrial revolution (Disse and Engel, 2001; Barriendos et al., 2003; Barrera et al., 2005). This choice was justified mainly because the coastal areas were unsafe for health and defensive reasons.

Over the last few centuries, production and mobility requirements have forced populations to concentrate on the plains, often in coastal areas, which, generally speaking, have typically fragile geological and ecological equilibriums of transition environments. Notwithstanding the fragile equilibrium, these regions have become of great social and economic relevance. The population moved toward large urban areas, which have sprung up in plains because of recent socio-economic and transportation advantages. In the

Published by Copernicus Publications on behalf of the European Geosciences Union. 


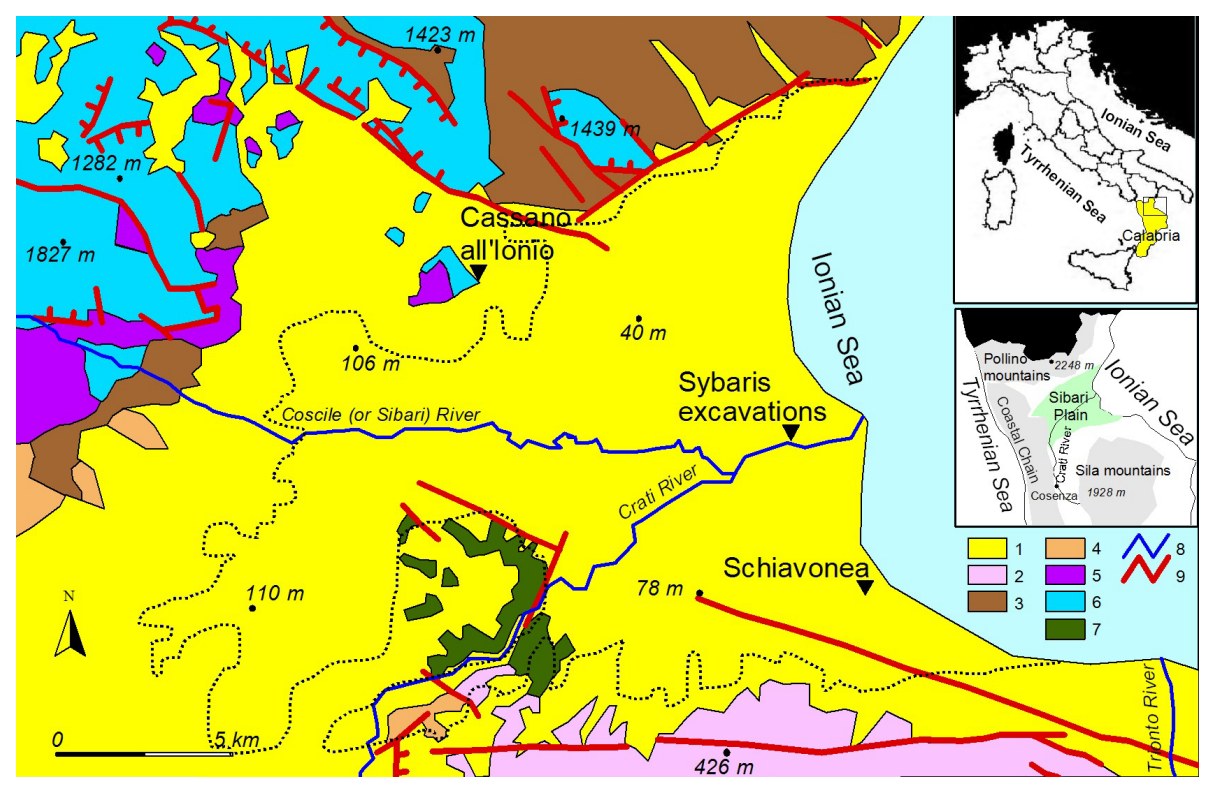

Fig. 1. Geological schematic map and location of study area (After Sorriso-Valvo and Tansi, 1995, simplified). 1) sedimentary lithotypes, mainly composed of sand and clay; 2) acid intrusive rocks and medium-to-high acid metamorphic rocks; 3) flysch; 4) coherent sedimentary terrains mainly composed of calcarenite and conglomerate; 5) low-grade acid metamorphic rocks; 6) limestone and dolostone; 7) low grade metamorphic rock: 8) main rivers; 9) fault lines (dashes indicate the lower side of normal faults). The number near the black dots indicates area elevation (ma.s.1.); the dashed line delimitates the studied portion of Sibari plain (under $300 \mathrm{~m}$ a.s.l.).

past, the anthropogenic use of coastal plains was obstructed because of both destructive river floods and the spread of malaria from the swamps located between the mouths of rivers.

Examples of this worldwide phenomenon can be observed in Italy, where, over the last two centuries, both local and national governments focused funding on coastal plains in order to promote their economic growth. This process induced the migration of poor people from the inner areas to the developing costal plains and encouraged uncontrolled agricultural or residential use of areas along riverbanks. This caused a conflict between the development of the plains and flood dynamics.

For these reasons, expensive national investments funded a program of protection works aimed both at mitigating river floods and reclamation of swampy areas (Ruini, 1913; Acerbo, 1937; Medici, 1954; Bevilacqua, 1987). However, these works encouraged a mistaken sense of safety with respect to flooding: local people occupied cultivable lands along riverbanks, even in flood-prone areas.

The effects of these works on the fragile equilibrium of basins were usually neglected. The reasons are both an overestimation of human capacity to control natural phenomena and the lack of specific knowledge of basin characteristics. The rivers of this region, widely observed in southern Italy, locally called fiumara, have ephemeral watercourses characterised by huge sediment load and flash and violent floods (Fairbridge, 1968).
Among the numerous examples of huge transformations of coastal plains, we analyse the case of the Piana di Sibari (Sibari plain, hereinafter), located on the northwestern coast of Calabria (southern Italy). The present work is based on a research concerning protection works aimed at: 1) the hydraulic reclamation of land; 2) protection from floods and 3) reduction of erosion and landslides in the high drainage basins. The series of structural works carried out during the last two centuries is discussed together with data concerning rainfall and flood damaging effects, taking into account the main land-use transformations and the modifications of the coast.

\section{The study area}

The plain inherited the name from Sybaris, the colony of Magna Graecia founded, around 730-720 BC, between the mouths of the Sybaris (nowadays Coscile) and Crati Rivers. According to Herodotus, the neighbouring Greek colony Kroton defeated Sybaris's army in 510 BC and they diverted the Crati River in the direction of the town of Sybaris, in order to destroy it (Liguori, 2000). Some Greek settlers rebuilt the town in $444 \mathrm{BC}$, with the name of Thurii, which became a Latin colony called Copia during the Roman period. The excavations locate the level of the Greek Sybaris from -2.5 to $-4.0 \mathrm{~m}$ a.s.l. and about $4 \mathrm{~m}$ below the ground surface (Cherubini et al., 2000; Guerricchio and Ronconi, 1997). 


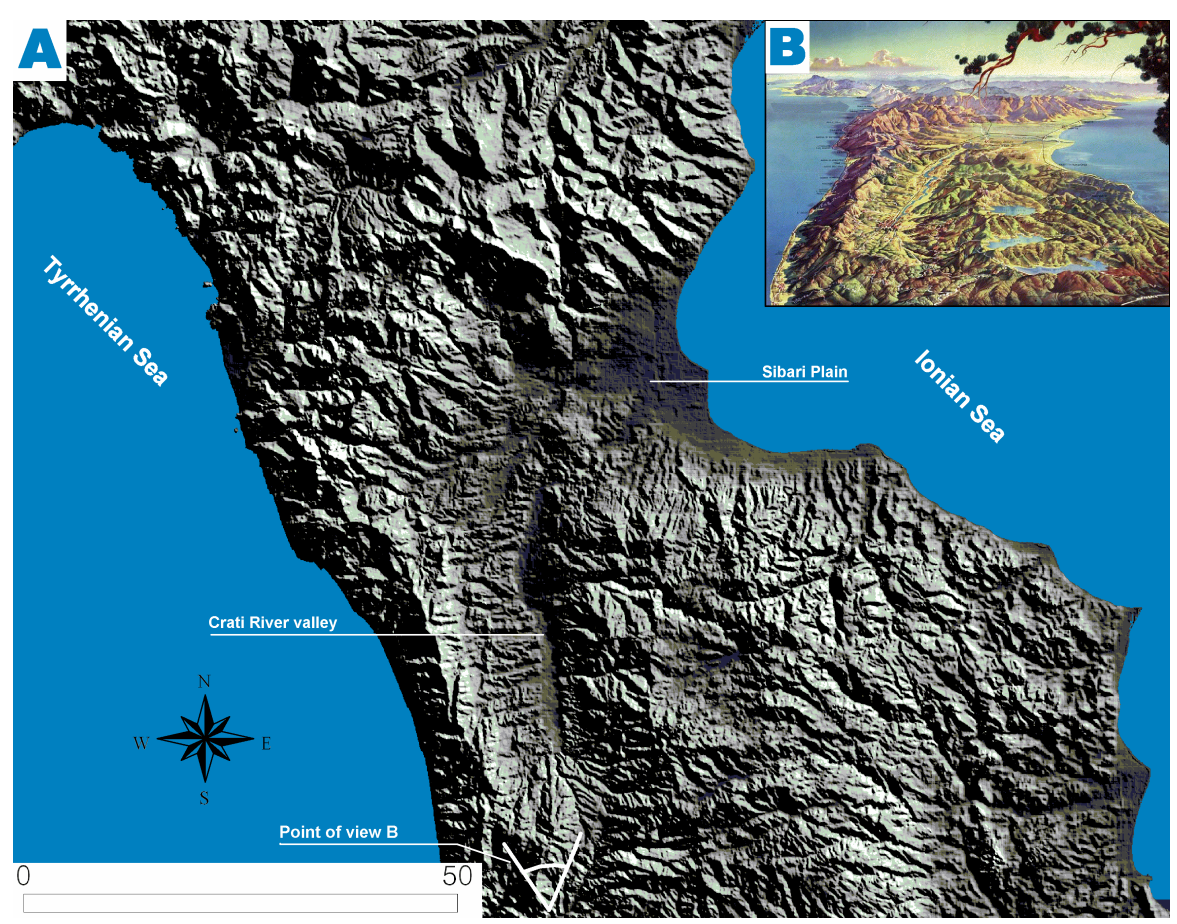

Fig. 2. Global view of study area and of surrounding mountains. (A) hill shade map and rough point of view of image B; (B) artistic bird's eye view made by H. C. Berann (1915-1999) with cartographic techniques (rough point of view on view A).

During the last two centuries, the river network of the plain was modified by hydraulics works designed to cope with both the flooding and swamps which caused widespread malaria. In this way, the plain was settled but the works influenced the local geo-hydrological and ecological equilibrium. At same time, these works had often led locals to believe, wrongly, that river floods had been defeated.

\subsection{Geological and hydrological framework}

The carbonate Mount Pollino to the North, metamorphic rocks of the Coastal Chain to the West, the granitic Sila Mountains to the South and the Ionian Sea to the East, where sandy beaches constitute the coast, bound the Sibari plain (Figs. 1 and 2). The plain includes the downstream part of the Crati River valley, $40 \mathrm{~km}$ long and with a SW-NE orientation, and the upstream sector, a plio-holocenic graben N-S oriented. Its width increases from inland to the coast, where it is about $40 \mathrm{~km}$. The maximum length of the plain (about $30 \mathrm{~km}$ ) is measured along the bed of the Crati River; the length decreases up to about $10 \mathrm{~km}$ outside the Crati basin.

The "Crati Valley-Sibari Plain" system began developing in the Upper Pliocene, from a gulf located between the Coastal Chain (at that time partially submerged) and the Pollino and Sila mountains (emerged at that time). After the low Quaternary, this gulf started to fill with fan delta sediments (Colella, 1989). About a million years before the present era, the gulf emerged and Crati and its tributaries car- ried sediments to fill the submerged part of the gulf, giving rise to the Sibari plain (Sorriso-Valvo, 1991). Over the last 5000-6000 years, sediments transported by the Crati River formed a cuspate delta (Ricci-Lucchi et al., 1985). The coastline moved from 1 to more than $8 \mathrm{~km}$ in the Holocene, thanks to progradation due to river sediment deposition (Guerricchio and Ronconi, 1997).

According to data of archaeological excavations and boreholes, the plain is constituted of heterogeneous soils about $400 \mathrm{~m}$ thick, mainly sand, gravel and clay, characterised by lateral heteropic contacts and peaty levels at different depths (Cotecchia and Pagliarulo, 1996). Such a stratigraphical structure can be linked to the overlapping of different sedimentary environments, occurred during the Quaternary because of the effect of river sediment deposition and the contemporaneous tectonic uplift (Guerricchio and Melidoro, 1975). This hypothesis is confirmed by the terraced deposits found at different elevations, and residues of marine terraces dating to the Sicilian-Milazzian (Vezzani, 1968). Fossil alluvial fans and river courses, going back to the different stages of evolution, were also found (Guerricchio and Melidoro, 1975).

Recent modifications concern the riverbed of Crati and its tributary Coscile, the course of which shifted during main floods, as in $510 \mathrm{BC}$, when the two rivers merged their courses, in 1595, when they separated and, finally, in 1794 when they merged again. 
The consolidation of sediments filling the plain makes the area prone to subsidence (Guerricchio and Melidoro, 1975; Cherubini et al., 2000). Guerricchio and Melidoro suggest that subsidence and river deposition are the main causes of the end of the Greek Sybaris (see Fig. 1). The maximum subsidence rate was estimated to be $4.3 \mathrm{~mm} / \mathrm{yr}$, based on dating and geotechnical tests and assuming $1.3 \mathrm{~mm} / \mathrm{yr}$ as a mean rate of sea level uplift (Guerricchio and Ronconi, 1997). The tectonic uplift rate of the area was estimated (probably overestimated) to be $0.877 \pm 0.06 \mathrm{~mm} / \mathrm{yr}$ (Cherubini et al., 2000; Lambeck et al., 2004).

The plain is crossed by 24 rivers, mostly fiumaras, 5 of which being tributaries of the Crati. Their drainage area ranges from $3 \mathrm{~km}^{2}$ to $82 \mathrm{~km}^{2}$, the only exception being the Crati River, which has a basin of $2460 \mathrm{~km}^{2}$, about $177 \mathrm{~km}^{2}$ of which extend into the Sibari plain.

Time series analysis of 31 climatic gauges, from 1916 to 2005 , shows a huge climatic variability in the analysed basins, the altitude of which ranges from $2248 \mathrm{~m}$ a.s.l. (Pollino Mt., located outside the study area) and sea level. The mean annual rainfall and temperature range respectively from about $2000 \mathrm{~mm}$ and $7^{\circ} \mathrm{C}$ on the Sila Mountains to $500 \mathrm{~mm}$ and $17^{\circ} \mathrm{C}$ in the Sibari plain. As an effect of this variability, the climate ranges from humid to arid. The mean annual rainfall, the mean annual temperature and the climate in the Sibari plain range respectively from 700 to $500 \mathrm{~mm}$, from 16 to $17^{\circ} \mathrm{C}$ and from semiarid to arid from inland to the coast.

River flow gauges exist in mountainous sector of the Crati River, some of which worked only for short periods (Versace et al., 1989). The Crati fluvial regimen is also affected by the presence of some artificial lakes created along its course. It is thus impossible to establish the peaks of river yield during floods that hit the Sibari plain or the variability of river flow over the past. The only available variables are rainfalls. Considering the variability of time of concentration of drainage basins, the main rainfall variable to be taken into consideration is daily rainfall. Versace et al. (1989) highlight that the Sibari plain is quite homogeneous in terms of both river flow and maximum daily rainfall.

The HYMAX database collects all available time series of daily annual maximum of rainfall, storing rainfall height, date of maximum and monthly rainfall and number of rainy days (days in which more than $1 \mathrm{~mm}$ of rain falls) over the monitoring period (1916-2005).

\subsection{Historical outline of the study area}

The history of the Sibari plain is typical for the plains of southern Italy, where major anthropogenic modifications were possible only by means of modifications of fluvial domains, with major effects on both the water cycle and the natural environment.

The pioneers of land reclamation in the Sibari plain, as in all Ionian side of Calabria, were the settlers of Magna
Grecia (8th-3rd century BC). At the decline of this civilisation, nomadic populations that gained the upper hand did not maintain the works carried out by Greek settlers and contributed to the formation of swampy areas. Afterwards, the Roman domination caused a widespread deforestation (Gambi, 1978) - to obtain the wood necessary to construct mercantile and military ships (Placanica, 1985). The wood production deeply modified the environment of inland areas contributing to an increase in erosion and landslide risks.

In the Middle Ages, the Sibari plain underwent an economic decline: all human activities were dangerous because of the spread of malaria, so people left settlements on the plain and withdrew to villages on the surroundings hills. During the 17th century, some of the swamps along the Coscile River were drained by means of channels called "Vene" (veins), some of which still work (Brunetti, 1995).

In the plain, the huge sediment load of rivers, favoured by landslides and erosion phenomena and increased by deforestation, created wide alluvial fans at the mouth of rivers. The low slope of the plain slowed down the runoff and the stream flow, creating swamps where malaria began to spread (Medici and Principi, 1939).

Starting from the mid 19th century, both flooding (damaging cultivated lands and roads), and malaria became urgent problems because they hindered the anthropogenic development of the plain. In that period, the construction of the railroad increased river network problems. In fact, because of the rugged regional morphology, the railroad was built along the coast, where the section of riverbeds is generally the widest and the slope the lowest. To minimise the cost of construction, the river flow was forced to cross narrowsection bridges. This choice decreased the riverbed width and the area where floods could dissipate their energy. In this way, floods become more dangerous than before.

\section{Methods}

The study methodology is based on the creation of a geodatabase, made up of a series of chronological data, to permit the multi-temporal and spatial analysis of the same series.

1) Historical series of geo-coded flood damage (DAMAGES database). Concerning natural events such as floods, the use of historical data, defining historical as the "period where human recorded information on specific events is available", is a complicated task (Ibsen and Brunsden, 1996; Guidoboni, 1995; Flageollet et al., 1999; Guzzetti, 2000; Glade, 2001; Glaser and Stangl, 2003; Barriendos et al., 2003). These data can be obtained from scientific articles and historical textbooks or from specific on-line databases, where available. AVI for Italy (CNR-GNDCI, 1995) and ASICal for Calabria (Petrucci and Versace, 2004) are examples of this type of database. Nevertheless, as tested in Italy, the largest amount of data comes from in-depth research in technical archives, both regional and local. Here, unpublished 
data concerning projects to reduce flood hazard are often hidden within thousands of applications for compensation after damaging floods. The results of historical research cannot be considered absolute because: 1) there are many accidental factors (fires, loss of documents during relocation of archives, etc.) which are potentially responsible for gaps in the historical series; 2) in uninhabited areas, a flood that did not cause damage is not well documented, because the "recording" of the event is mainly tied to damage compensation claims. However, the historical series should be representative of "major" flood events occurring in the study area if the crosschecking of data coming from different archives validates it.

2) Geocoded series of protection works for land reclamation, protection from floods and improvement of soil stability in steep areas (WORKS database). From the archives of the agencies that carried out the works, data concerning planning and building phases must be extracted, tabulated, and organized in a GIS-compatible format. Generally, the series of data that could be collected is complete but some gaps in it can depend on the fact that some of the agencies that carried out the works have closed down or have changed their core mission and have abandoned maintenance of the archives

3) Historical series of maximum flood discharges and extreme rainy events (HYMAX database). The collection of hydrological data primarily concerns the value of maximum discharges and the frequency of flood events where frequency and density are adequate to characterize the trend of occurrence and intensity of flooding. In the case of unavailability of these data, or in order to complete the database, the maximum rainfall events of duration roughly equal to the time of concentration can compensate for the unavailability of river yield data and it can permit a clearer understanding of the effects of long-term climatic modifications on the frequency of damaging floods.

4) Coastal line position and migration over time (COASTAL database). This discontinuous historical series generally supplies important data concerning the dynamic equilibrium between river discharge, sediment load - which varies widely due to anthropogenic modifications - and the dynamics of the sea. These data can be acquired from the literature or comparing coastline positions from the overlapping of maps, aerial photographs and satellite images. The trend of the combined results of eustacy, glacio-hydroisostasy and vertical tectonic movements must also be considered. The overlapping data pinpoint the costal sectors affected by erosion and the ones in which sediment accumulation and the progradation prevail. Once the time during which the highlighted modifications occurred is known, the rate of the processes can also be roughly assessed. The analysis of data can highlight the superimposed effects of different types of works carried out, and the accuracy of forecasted effects (if available) assessed before the construction.

The whole approach describes the complex succession of floods, protection and reclamation works, human transforma- tion of the plain and major land use changes. Ultimately, the approach yields recognition of the new characteristics of the plain and the trends of its modifications, highlighting the role of major engineering works, land-use transformation and urbanisation. This analysis is carried out taking into account geomorphological and hydrological phenomena and their effects in terms of natural hazards, focusing on vulnerability to flooding (Barrera et al., 2005), and carrying out an analysis of benefits and disadvantages to the natural equilibrium and to human activities. Examples of disadvantages are the decrease in sediment transport from inland to the coasts for beach replenishing and flooding damages to new settlements constructed in flood prone areas, which are mistakenly considered safe because of the construction of protection works.

\section{Results}

Based on the proposed methodological approach, the four databases have been organised and analysed for the study area.

\subsection{Historical series of geo-coded flood damage}

A huge amount of data concerning flood damage in the Sibari plain from 1811 to today was found and analysed. The oldest data concerns floods occurred in the first half of the 19th century that affected the only road existing at that time ( $\mathrm{La}$ Regia strada delle Calabrie). These data have not been analysed because one of the research purposes was the analysis of flood damage and protection works relations, but no protection works were carried out in that period. At any rate, finding a number of documents concerning damage occurred so long ago, in a sparsely populated area and in such a short period, denotes a high frequency of damaging floods.

The majority of data describes flood events damaging the railway or the national road N. 106, also called the Ionian road. These two routes, almost parallel to the Ionian coastline, were the most important ones located in the Sibari plain. Other frequently damaged elements are the cultivated areas and the protection works, mainly the embankments along the final reach of the rivers.

In order to analyze the sequential modification of the damaging events, six time intervals (1891-1910; 1911-1930; 1931-1950; 1951-1970; 1971-1990 and 1991-2006), each 20 years long, except for the latest (which is 15 years long) are considered. It can be observed that the number of damaging floods (Fig. 3c) seems to be decreasing. The main exception is observed from 1951 to 1970 when the highest percentage of events happened. The 1951-1970 period had not only much higher rainfalls than normal over the entire Calabria but also in the whole context of southern Italy (Polemio and Casarano, 2004). During this period, in 1951, 1953 and 1959, exceptionally heavy rainfalls hit the entire Calabria, damaging property and persons. Basin 15 suffered the 


\begin{tabular}{|r|l|r|}
\hline \multicolumn{2}{|r|}{ River } & $\begin{array}{r}\text { No. of } \\
\text { floods }\end{array}$ \\
\hline 1 & Saraceno & 2 \\
\hline 2 & Satanasso & 6 \\
\hline 3 & Caldanello & 10 \\
\hline 4 & Raganello & 12 \\
\hline 5 & Coscile & 15 \\
\hline 6 & Crati & 24 \\
\hline 7 & Tiro & 0 \\
\hline 8 & Esaro & 7 \\
\hline 9 & Galatrella & 3 \\
\hline 10 & Muzzolito & 4 \\
\hline 11 & S. Mauro & 8 \\
\hline 12 & Malfrancato & 7 \\
\hline 13 & Coriglianeto & 9 \\
\hline 14 & Gennarito & 2 \\
\hline 15 & Cino & 22 \\
\hline 16 & Grammisati & 6 \\
\hline 17 & Momeno & 1 \\
\hline 18 & Fellino & 1 \\
\hline 19 & Acqua del Fico & 3 \\
\hline 20 & Citria & 7 \\
\hline 21 & Colognati & 15 \\
\hline 22 & Coserie & 8 \\
\hline 23 & Nubrica & 2 \\
\hline 24 & Frascone & \\
\hline & & \\
\hline
\end{tabular}
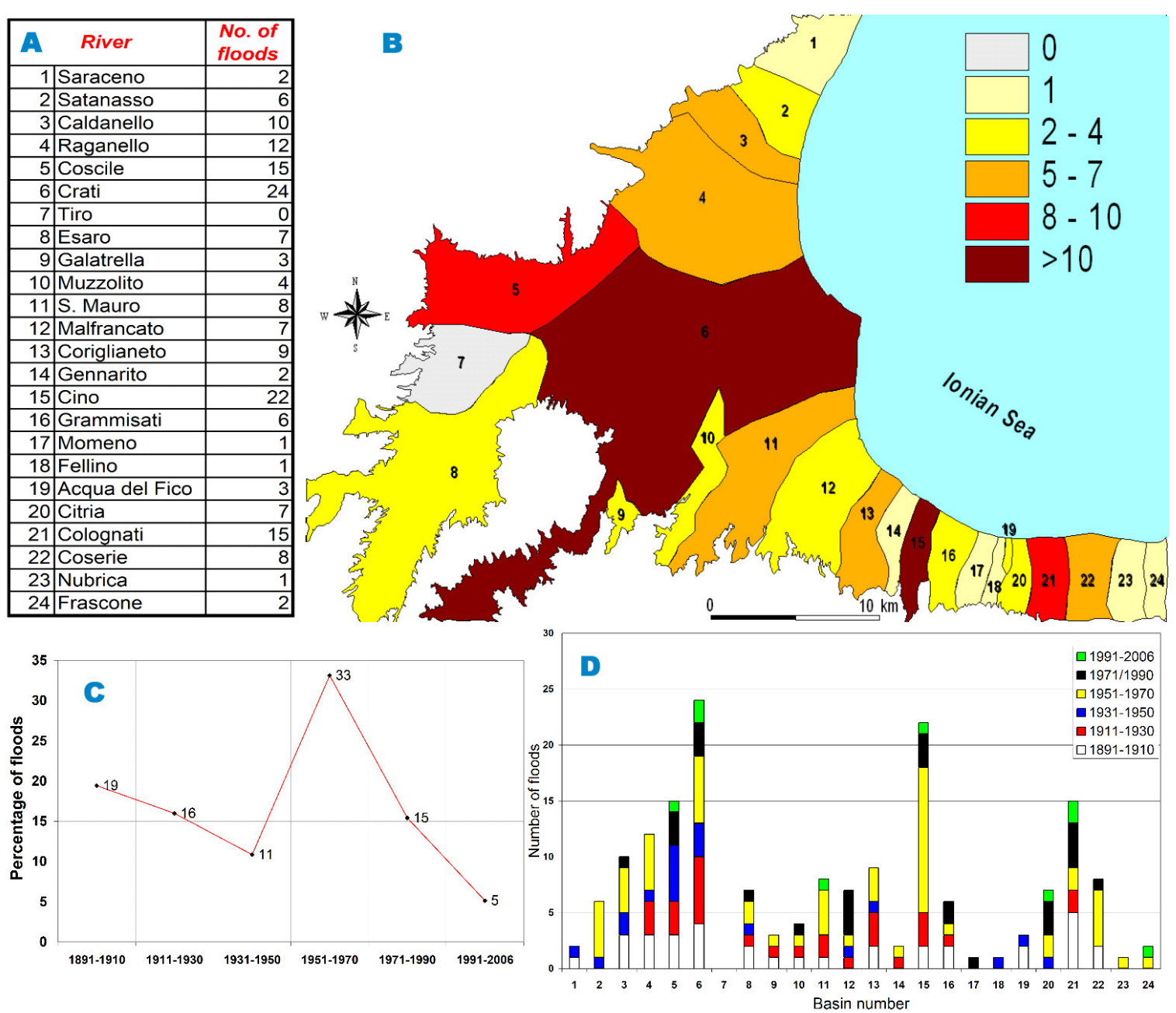

Fig. 3. Floods recorded in each basin of the Sibari plain from 1891 to 2006 . (A) Number of floods for each basin and basin number; (B) basin classification according to the percentage of floods occurred in each basin; (C) number of floods over the different time intervals; (D) number of flood events in each basin and each time interval.

highest number of events in this period, even thought most basins were also affected (Fig. 3d).

After 1970, the number of floods seems to be more in line with the values of the oldest intervals. The minimum value has been recorded during the latest period, in the 15 years from 1991 to the present day ( 9 cases, 5\% of the total). This recent decrease of damaging floods can be explained by taking into account decreasing rainfall trends, probably due to an anomalously frequent succession of exceptional drought periods observed starting about from 1980 (Polemio and Casarano, 2004), and to rainy day intensity, as shown below.

Making a simple proportion and normalising this value to twenty-year periods, a value of 12 cases can be extrapolated; according to this extrapolation the predictable percentage of floods for 1991-2010 period would be about to 7\%, less than the value recorded between 1931 and 1950 .
4.2 Geocoded series of protection works and major land transformation

Historical research concerning protection works built on the Sibari plain has been carried out mainly in the archives of the Corps of Engineers, but also in the State Archives of Cosenza and the archives of the Middle Crati Valley Consortium. Documents concerning 271 works, carried out between 1891 and 2002, were found.

Each work record collects main dates (project beginning and completion dates), geographical location, main dimensions, drainage basin and classification. A simple classification of works is based on four types.

Type A consists of modifications to the riverbed in the low portion of the river due to new works or completion of existing inadequate works. They are generally dikes, embankments and drainage channels created for flood control and 
reclamation of swampy areas, including lowering the shallow water table with drainage channels.

Type B consists of works in the upward part of the plain and in the mountainous and hilly portions of the basins. Their purpose is to reduce landslide and erosion effects on the slopes and sediment transport along the low order channels, essentially by means of gabions, check-dams and reforestation of bare soils.

Type C consists of ordinary maintenance of existing works.

Type D consists of repairing works or extraordinary maintenance and reinforcement of works when damaged by floods.

Type A of works is the most frequent (45\% of total), followed by type $\mathrm{D}(36 \%)$, according to the two main types of problems affecting the area: necessity of land reclamation and flood protection or repairing flood damage.

In order to make comparable the transformations carried out in the different basins, the number of works achieved in each basin has been normalised to the basin area and multiplied by 100 , obtaining the density of works; the same density can be determined distinguishing each type of work (Fig. 4).

Type A works concern all the basins except N. 7. Type B is concentrated in the high part of the basins, characterised by the highest percentage of areas affected by landslides or erosion phenomena, mainly in the sectors upwards of the Sibari plain, the maximum altitude of which is about $300 \mathrm{~m}$ a.s.l. Type $\mathrm{C}$, routinely maintenance works, seems inhomogeneous respect to basins, probably due to data gaps for the smallest basins. On the contrary, Type D shows an almost homogeneous spatial distribution, according to a generalised high frequency of damaging floods that require repair works.

Many basins, showing the highest flood frequency, had been affected by works of type A and B. Of these basins, many had also works of type D, as in the case of basins 13 , 15,20 and 21, indicating the low efficiency of the works carried out.

In order to schematize the sequential construction of works, these data, as well as the flood damage series, have been divided into six reference periods (Fig. 5).

Works started between 1891 and 1910, being mainly repair works after floods, besides some cases of Type A works, interesting Crati River basin and its tributaries. This is in line with the philosophy of the time, which was mainly focused on local protection works, which were not part of a global context of protection against geo-hydrological hazards in the whole drainage basin. Most works of all four types were carried out in the periods 1911-1930 and 1951-1970, in accordance with specific national laws. In the latter period, type $\mathrm{D}$ or repair-reinforcement works prevailed; in the former period, after the inactivity of the 1931-1950 period, which included the devastation of the Second World War, type B prevailed, though there was a considerable amount of each type of works, including type $\mathrm{C}$, which was the necessary
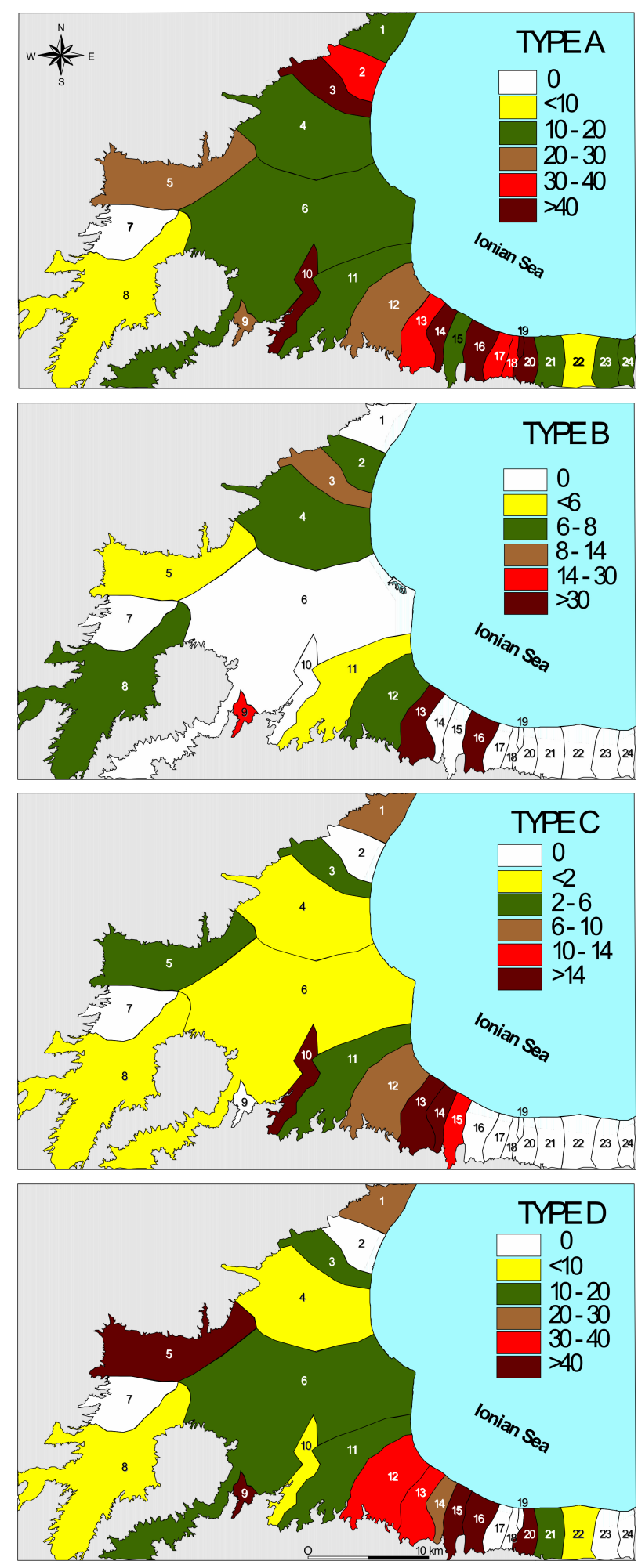

Fig. 4. Density of works classified by type (number of works/basin area $\left.\left(\mathrm{km}^{2}\right) * 100\right)$. 

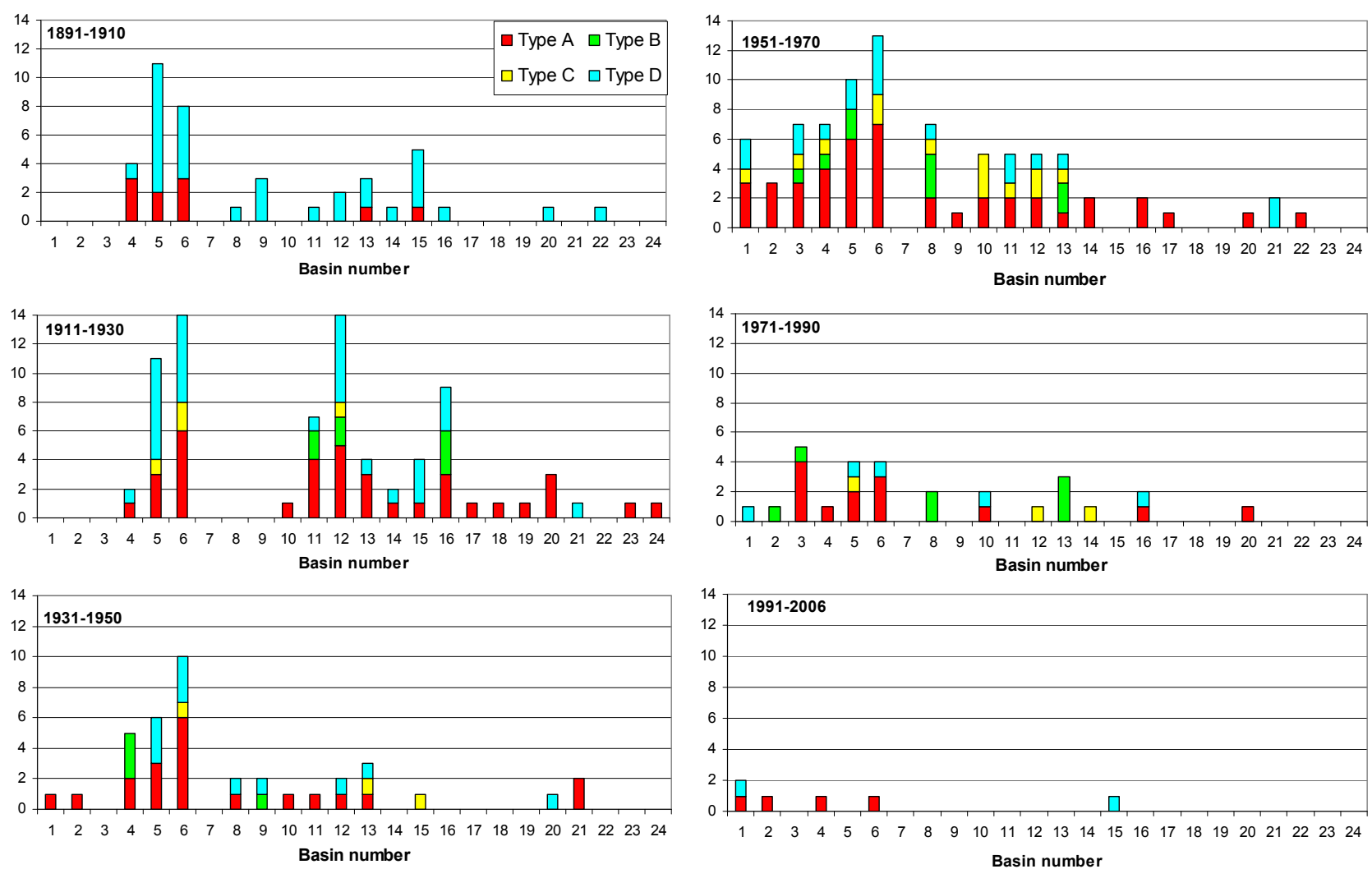

Fig. 5. Number of works of Type A, B, C, and D carried out during the study period (subdivided in twenty year periods) in the basins of the study area (identified by basin number).

yet often neglected ordinary maintenance. It can be assumed that the determination felt from 1951 and 1970 to reduce the impact of floods was due to the effects of the catastrophic floods of 1951, 1953 and 1959. In any case, the wider approach used from 1951 to 1970 , considering the entire basin, shows some appreciable results, considering the decreasing number of works of type D after 1970. Since the decrease in type $\mathrm{D}$ works was also due to the favourable climatic conditions prevailing from about 1980 onwards, the effectiveness of works carried out from 1951 to 1970 can be only qualitatively assessed.

The complete reconstruction of the series of all works carried out in the Sibari plain is complicated by two factors: a) the works have been carried out over a time span of more than 100 years, during different and separated phases, according to the availability of financial support. Sometimes they were completed and sometimes planned but never carried out because of cuts in funding, such as during the First and Second World Wars; b) different agencies carried out works, therefore there is no one overall homogeneous archive containing documents concerning "all" the works carried out, but rather there are many different archives. Moreover, some of these agencies are no longer in existence or have a changed mission so their old archives are not conserved or easily consultable.
The earliest works of land reclamation and local protection from floods along the Crati River and the remaining main regional rivers began at the beginning of the 20th century and progressed by discontinuous steps because of a lack of both funding and hydraulic knowledge of fiumara rivers. The benefits of these works were negligible because they were extremely localised and carried out without considering the entire drainage basin. The idea that "the reclamation of the plains depends on the condition of the high basins" (Ruini, 1913) was far from being established and accepted.

After Law N. 3256 of 1923 concerning hydraulic reclamation and soil protection was passed, five Reclamation Consortia were founded in the Calabria region, including the Sibari and Middle Crati Valley Consortium, which become operational only from 1954 onwards. The territory managed by this Consortium included the entire plain and a wide portion of the surrounding hills, for a total area of $1460 \mathrm{~km}^{2}$ (Brunetti, 1995).

Despite the fact that the first reclamation project in the Sibari plain was completed in 1926, an organic approach to the problem started in the 1950s, as an effect of specific laws (Laws N. 646/1950, N. 1177/1955 and N. 437/1968). Legislators established a more appropriate scale for reclamation work on this type of plain and earmarked considerable funds, 
also in order to solve social problems as poverty and low unemployment rate.

The works, carried out systematically from 1951 to 1970 , starting from the widest basins, trying to reduce both landslide and erosion effects in the high portion of basins and constructing continuous embankments in plain areas (Fig. 5). Afterwards, a series of artificial channels in the sectors between the riverbeds of the main watercourses and the sea were created in order to empty out and to permanently dry swamps.

The system started to work well: swampy areas decreased and flood-mitigation efforts became useful in preventing natural damage. Starting in the 1950s, the so called Italian land reform expropriated land from large landowners in a number of wide plains subject to reclamation. Small groups or families of farm hands or of unemployed persons settled in these areas, owning smallholdings. Many hundreds of families were transferred to the Sibari plain; they received a house, built in small groups on the plain, including shallow wells, and 2 or 3 ha of farm land, a few more than the minimum necessary for subsistence. A network of "reclamation roads" was created, as were many common buildings and services. The Sibari plain reforms have been much more successful than others, creating durable social and economic development, even though the model of scattered farmhouses and widespread land ownership was unsuccessful given the small size of the holdings (Rother, 1986).

Both the elimination of the Anopheles mosquito, which is responsible for the spread of malaria, by means of DDT (Dichloro-Diphenyl-Trichloroethane), and the vaccination of the population worked together to defeat malaria. A phase of new settlements began on the Sibari plain, subsequent to the agricultural and industrial development of the area, which had been modernised thanks to an efficient irrigation and road network. These improvements show clear effects on the population that started growing after 1910, reaching the maximum rate after 1950 in the example of Cassano all' Ionio municipality (Fig. 6). This trend was quite common in the entire region up until the 1950s; population declined in the region as a whole after the 1950s due to emigration. At same time, a large and well-designed program of socio-economic development started, with adequate and continuous funding from the Cassa per il Mezzogiorno (hereinafter CASMEZ), a special fund dedicated to the social and economic growth of southern Italy.

Though not all the economic goals were achieved, yet in the sector of protection against natural risks the entire action plan can be considered a fruitful endeavour, having improved the safety and exploitability of large areas (Petrucci and Versace, 2005).

Besides the above-quoted works, two important projects were carried out in the Sibari plain. The Tarsia dam, finished in 1966, created an artificial lake accumulating a maximum water volume of 16 million $\mathrm{m}^{3}$, meeting industrial and irrigation water demand and contributing to flood peak reduction.

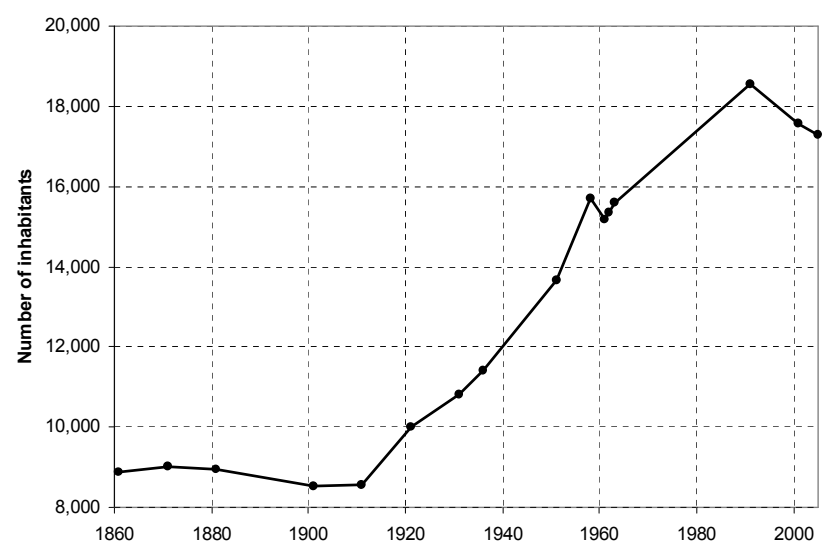

Fig. 6. Number of inhabitants of Cassano all'Ionio municipality (see Fig. 1 for the location) from 1860 to 2006.

The Sibari lakes consist of a recreation harbour for small tourist boats, created by modifying a lowly drained sector of the Sibari plain. An artificial channel called Stombi conveys water toward the sea.

Starting from the end of the 1960s, subsequent to the municipal and private funding of local small canned food industries, rural development of the plain accelerated. Tourism along the coast grew, at first as an effect of the progressive economic development of the region; after the 1960s, greater development was due to broad initiatives not only of single well-off families but also of small companies, which progressively created new inhabited areas located on the coast. After that, heavy investments by large companies were made to create large tourist resorts along the coast, especially at the end of 1970s.

The progressive economic transformation and development required more efficient transportation systems. The effect is an increasing portion of surface covered by roads and the construction of bridges and protection works for bridges and road embankments, which had a strong effect on flood flow especially near the coast, along which main roads are located.

A drastic drop in woodlands, pastureland and uncultivated fields can be observed by comparing the situation of 1900 to that of 1968: there was a sharp rise in cultivated areas and anthropogenic areas (houses, factories, infrastructures and mainly roads) (Brunetti, 1991).

\subsection{Historical series of maximum flood discharges and ex- treme rainy events}

The Sibari plain, the whole area of basins located in the Sibari plain and the overall Calabria have been the subject of researches on climate change also considering the wider context of Southern Italy (Mendicino and Versace, 2002; Polemio and Petrucci, 2003; Polemio and Casarano, 2004; Coscarelli et al., 2004). Analysis of monthly and annual 


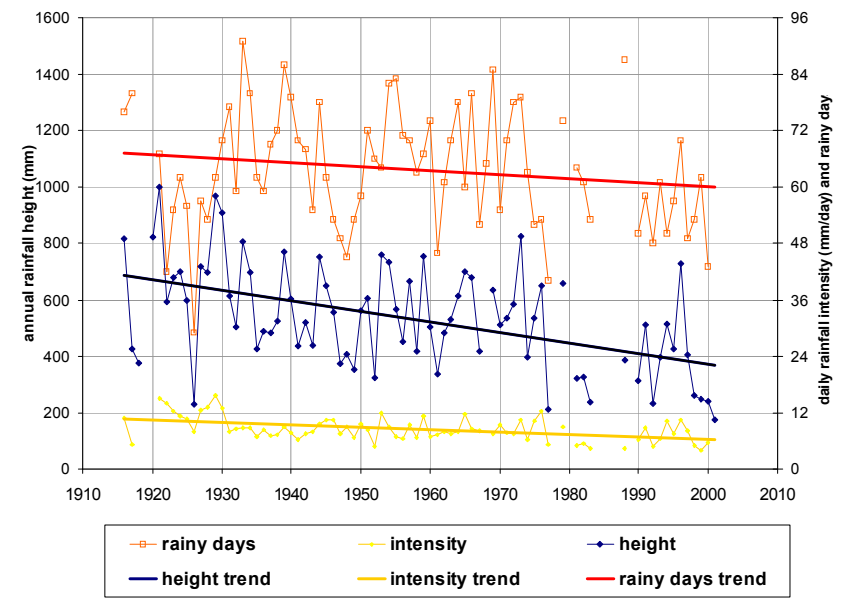

Fig. 7. Annual rainfall height, rainy days and rainy day intensity time series and trends at the Schiavonea gauge (3 m a.s.1.).

rainfall series shows a huge and widespread drop in rainfall trends at all three scales: the Calabria region, the total area of basins and the Sibari plain. The application of the MannKendall test confirms the statistical significance of detected trends; the results are also consistent with analyses carried out taking into consideration all of southern Italy (Polemio and Casarano, 2004). The drop seems to be due to an anomalously succession of exceptional drought periods observed starting about from 1980.

The greatest drops are observed for autumn and winter, the seasons in which the highest damaging floods happen; during summer, the trend is in places slightly on the rise. The decreasing trend increases from the coast to inland, showing a good correlation with altitude. In the Sibari plain the statistically significant annual rainfall trend ranges from -3.7 to $-0.5 \mathrm{~mm} / \mathrm{yr}$, though it should be borne in mind that the last drought ending in 2002 was exceptional and some data gaps have been observed after 2002. The drop in annual rainfall is sharpest at the Schiavonea gauge, located near the coast. The trend is equal to $-3.7 \mathrm{~mm} / \mathrm{yr}$. The Mann-Kendall test corroborates the trend. This is significant even at a significance level of 0.001 (Fig. 7). The trend of annual rainy days, the number of days in which rainfall is greater than $1 \mathrm{~mm}$, is negative and is equal to -0.1 day/yr at Schiavonea but the trend is not significant at the level considered. The negative trend of rainy days is the most frequent in the Sibari plain but the Schiavonea figure is widespread over the entire study area in which the rainy day trends seem negative but are not statistically significant elsewhere. Generally speaking, the variable rainy days is useful for the purposes of this article not so much for the analysis of its time series but for calculating the annual time series of the rainy day intensity, determining the ratio between annual rainfall and annual rainy days. The rainy day intensity ranges from 4.0 to $15.6 \mathrm{~mm} /$ day at the Schiavonea gauge (Fig. 7), which has a negative trend

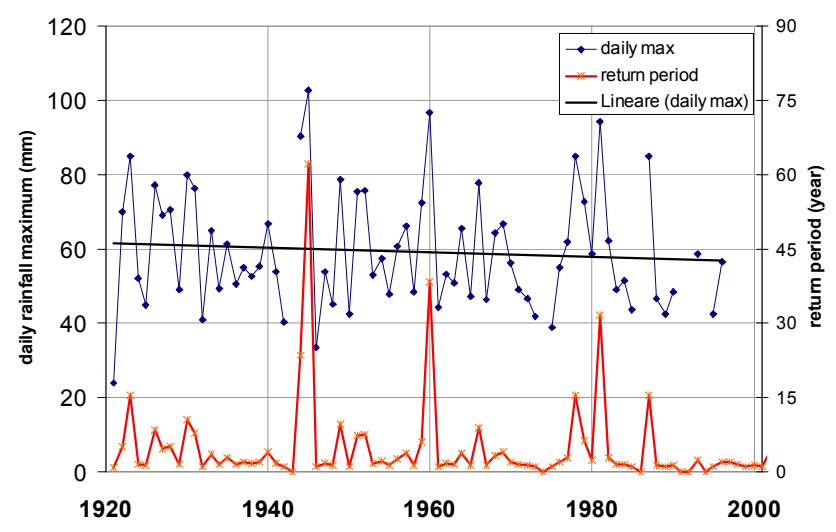

Fig. 8. Time series, trend and return period of annual maximum of daily rainfall at the Cosenza gauge (250 $\mathrm{m}$ a.s.1.).

and is equal to $-0.05 \mathrm{~mm} /($ day $\mathrm{yr})$; the trend is verified at a level of significance of 0.001 ; the results of Schiavonea are significant for the entire study area.

Rainy day intensity, rainfall and temperature time series show an abrupt variation from about 1980 onwards. The latter variable shows a generalised increase which, while not the cause of a broadly linear increasing trend which is statistically significant, does nonetheless contribute to the enormous rise in evapotranspiration in southern Italy, from about 1980 onwards, as observed by Polemio and Casarano (2004). Taking the entire water cycle into account, there have been unfavourable conditions in terms of net rainfall -and then for the runoff- due to the decrease of rainfall and the increase of actual evapotranspiration over the last few decades.

If the drop in rain intensity during rainy days is also taken into account, it seems realistic to hypothesise a drop in mean river discharge in all the rivers flowing on the Sibari plain. The decrease in river flow is also favoured by the withdrawals by artificial lakes, which began in the 1960s. The whole effect should be a slowing down of any phenomenon of fluvial dynamics, with a decrease in both sediment load and river erosion capacity.

Ten time series of Annual Maximum of Daily Rainfall, hereinafter AMDR, have been selected in the entire area of drainage basins to acquire more details concerning extreme hydrological conditions (data from 1921 to 2005). The trend of the AMDR series is statistically significant only where negative; the percentage of significant time series trends goes down to $25 \%$ if a significance level of 0.05 is considered. The decreasing trend is equal to $-0.2 \mathrm{~mm} / \mathrm{yr}$ in the Cosenza time series (Fig. 8). For each AMDR times series, the GEV (Generalised Extreme Value) probability distribution function (Jenkinson, 1955) has been determined, using the PWM method (Probability-Weighted Moments), to estimate parameters (Hosking, 1986); the obtained functions show not less than a $95 \%$ of level of confidence. The main purpose of this application is the assessment of the exceptionality of 
the annual AMDR values in terms of return period (Fig. 8). From 1980 onwards, only $40 \%$ of the time series shows one or more events with return periods greater than 10 years, as in Fig. 8, and from 1988 only 20\% shows similar results. AMDR time series show a clear decrease from circa 1980 on, as well.

Decreasing trends are widely observed also in the case of annual rainfall and of rainy day intensity. These trends seem due to a variation that starts, generally, from about 1980.

Summarizing the effect of recent climate trends, each phenomenon triggered by runoff and river flow should be substantially slowed down over the past decades.

\subsection{Coastal line position and migration over time}

Relative sea-level changes along the Italian coasts - the combined result of eustasy, glacio-hydro-isostasy and vertical tectonic movements - exhibit considerable spatial and temporal variability throughout the Holocene. The Italian peninsula cannot be considered to have been tectonically stable during the Quaternary and longer timescales. It comprises $\sim 8000 \mathrm{~km}$ of coastline of which approximately $25 \%$ consists of low-lying plains, some of which are subsiding, with a high risk of becoming submerged. Estimates of the average vertical tectonic uplift and subsidence rates show uplift trends in the whole of southern Italy, where the peak for the Sybaris plain, which is probably overestimated, is equal to an uplift rate of $0.877 \pm 0.06 \mathrm{~mm} / \mathrm{yr}$ (Lambeck et al., 2004).

The combined effect of the high rate of sediment load, tectonic uplift and subsidence of the plain, is a natural trend of the progradation of the Sibari plain coast, the shifting of which was estimated from 1 to more than $8 \mathrm{~km}$ in the Holocene (Guerricchio and Ronconi, 1997).

Data concerning the shifting of the coastline over the past centuries have been collected. An analysis of modifications of the Crati River mouth between 1789 and 1998, carried out using cartographic and aerophotographic data, showed different phases leading to growth and southwards displacement of the delta, characterised by a marked symmetry of its sides mainly because of embankments built along the riverbed mouth (Zecchi et al., 2003).

The works of reforestation, fluvial engineering and slope stabilisation permitted both an improved use of the plain and reduced sediment load but not reduced marine erosion notwithstanding the ongoing, at times unauthorized, practice of extracting gravel and sand from the riverbed and banks. The negative effects in term of coastal erosion started to be relevant for the local communities particularly from the 1980s on, due to the construction of tourist resorts.

A national research project concerning Italian coastlines showed that some coastal sectors of the Sibari plain were affected by erosion (CNR, 1985). Based on data available in the 1980 s, the coastline is, in places, subject to erosion and retreats and in places subject to advances, given the different effects of marine sediment load, flowing locally from south to north, with respect to mouth embankments and notwithstanding the high uplift trend of the area.

The regional River Basin Authority of Calabria, in its recent Geo-hydrological Plan (Regione Calabria, 2001), substantially confirms the results of the CNR (1985). The increasing accuracy of analysis, as in the work of Veltri and Fiorini Morosini (2003), shows the relevant effect of longshore transportation of sediment. Where the effect of this flow is hindered on the south side of mouth embankments, as in the case of Stombi channel, very high or maximum advances are observed, while huge retreats are observed on the north or downward side. Coastline retreats are more dangerous near Rossano Calabro while the advances are widespread mainly in the sector of Cassano allo Ionio (Veltri and Fiorini Morosini, 2003).

\section{Discussion and conclusions}

The research has analysed the damaging floods of the last 200 years in a coastal plain taking into account the entire basin of each river of the plain. All works carried out over the area causing effects on runoff and flooding have been considered, creating a database and a GIS in which these data can be quickly analyzed in terms of typology, location and extension.

The analysis considers each river basin as an entity that feels the combined effect of the natural and anthropogenic modifications carried out in each part of it. This approach leads to a possible contrast between the reduction of inland effects of widespread erosion, landslides and floods and the inland protection from hydro-geological hazards from a side and the disappearance of the sandy beach in tourist areas and the protection of human activities located near the coastline from the other side.

Summarizing the main results, the following comments can be made. Works carried out up to 1950 were exclusively of type A and D, mainly dikes, embankments and the extraordinary upkeep of existing protection works. In any case, the approach is extremely local: short embankments to construct dikes to protect specific relevant areas (villages, bridges, ...) without continuity along portions of rivers. In these cases, the design does not take into account the entire drainage basin and does not attempt to predict the lasting effects of works either upstream or downstream.

The works are generally quite simple and very often consist of reinforcements and enlargements of pre-existent works. The main criterion is: where floods occur and cause damage, create a larger, longer or higher work to avoid it happening again!

The coastal plain was affected by a wholesale transformation after 1950 brought about to solve social and health problems due to the unhealthy environment for a number of human activities along the coast and to reduce the flooding 
risks for new economic activities (industrial activities linked to agricultural production).

The country funded the program, leading to a global transformation of both the plain and the upland territories. According to a new global approach, large-scale hydraulic and reforestation works were carried out (Type B), together with the construction of large and continuous dikes (Type A), both to protect the population and to open new areas to agriculture, or offering free land to farm hands.

From the 1960s on, construction of artificial lakes has contributed to a better anthropogenic control of flood peaks and to the availability of water for irrigation.

There were very few damaging floods from 1991 to 2006 (9 cases, one for each of basins 5, 11, 15, 20, 24 and two cases for basins 6 and 21), highlighting a probable success of the works, though climatic conditions were quite favourable in this sector of southern Italy.

Though there is a drop in damaging flood frequency, flood risks are greater due to the rise in population and to the number and value of businesses located near the embankments or in riverbeds. Increasingly high banks could further augment vulnerability and create hanging riverbeds in the future.

Works constructed over broad stretches in the uplands of the plain reduce sediment flow reaching the coast. At same time, both the withdrawal of sediments from riverbed, and the effect of climate trends on river flow worsen sediment flow reduction, which should be considered a negative effect of past management choices. Coastal erosion, notwithstanding the reduction of sediment load from rivers and the unfavourable effect of climate on runoff, shows only localised negative effects (Regione Calabria 2001; Veltri and Fiorini Morosini 2003). The overlapping and concordant effects of different phenomena, such as the construction of works to reduce erosion, landslides and floods, the extraction of river sediments and climate variability are currently low and quite balanced along the coastline. The combined effect of the remaining sediment load, borne directly to the Sibari plain coast, the long-shore sediment contribution, coming from the south and mainly fed by the Trionto River (Fig. 1) and tectonic uplift have until now protected the coastal settlement from widespread erosion damage.

The proposed approach pointed out the strong correlation between drainage basin management, protection from natural hazards and anthropogenic development in a wide coastal plain.

Further research is planned using databases for a numerical simulation of the effects of recent modifications of the plains, based on rainfall-runoff modelling and taking into account the presence of hydraulic works. The focus will be on last few decades, for which more high-quality data are available, in order to quantify the impact of recent climatic trends on the reduction of damaging floods.
Edited by: A. Loukas

Reviewed by: two referees

\section{References}

Acerbo, G.: La bonifica integrale e la sistemazione montana, Dal Regno all'Impero, Roma, Italy, 1937.

Alcantara-Ayala, I.: Geomorphology, natural hazards, vulnerability and prevention of natural disasters in developing countries, Geomorphology, 47, 107-124, 2002.

Barrera, A., Barriendos, M., and Llasat, M. C.: Extreme flash floods in Barcelona County, Adv. Geosci., 2, 111-116, 2005, http://www.adv-geosci.net/2/111/2005/.

Barriendos, M., Coeur, D., Lang, M., Llasat, M. C., Naulet, R., Lemaitre, F., and Barrera, A. Stationarity analysis of historical flood series in France and Spain (14th-20th centuries), Nat. Hazards Earth Syst. Sci., 3, 583-592, 2003, http://www.nat-hazards-earth-syst-sci.net/3/583/2003/.

Bevilacqua, P.: La bonifica nel Mezzogiorno d'Italia: alcune considerazioni. Rivista di Storia dell'Agricoltura, Accademia Economico-Agraria dei Georgofili, Firenze, Italy, 2, 1987.

Brunetti, D.: Cronotassi dell'agricoltura e della bonifica nella Piana di Sibari, Arti grafiche Joniche, Corigliano Calabro (CS), Italy, 1991.

Brunetti, D.: Quarant'anni di Attività del Consorzio di Bonifica della Piana di Sibari e della Media Valle del Crati, Ed. Grafosud, Rossano (CS), Italy, 1995.

Cherubini, C., Cotecchia, V., and Pagliarulo, R.: Subsidence in the Sybaris Plain (Italy), Proceedings of the 6th International Symposium on Land Subsidence, Land subsidence, 1, 3-15, 2000.

CNR (Consiglio Nazionale delle Ricerche): Atlante delle spiagge italiane. Progetto Finalizzato Conservazione del Suolo, Sottoprogetto Dinamica dei Litorali, Roma, Italy, 1985.

CNR-GNDCI: Progetto AVI, Censimento delle aree vulnerate da calamità idrogeologiche, Rapporto di sintesi, Calabria. Grifo, Perugia, Italy, database available at: http://avi.gndci.pg.cnr.it/, 1995.

Colella, A.: Il Bacino del Crati (Calabria Settentrionale), Sviluppo N. 58, Cosenza, Italy, 1989.

Coscarelli, R., Gaudio, R., and Caloiero, T.: Climatic trends: an investigation for a Calabrian basin (southern Italy), The Basis of Civilization - Water Science?, IAHS Publ. 286, 255-267, 2004.

Cotecchia, V. and Pagliarulo, R.: State of the art in geological, hydrogeological and geotechnical researches carried on the archaeological site of Sybaris, Geologia Applicata e Idrogeologia, 31, 43-54, Bari, Italy, 1996.

Disse, M. and Engel, H.: Flood Events in the Rhine basin: Genesis, influences and mitigation, Nat. Hazards, 23, 271-290, 2001.

Fairbridge, R. W: The encyclopedia of geomorphology, Reinhold, New York, 1968.

Flageollet, J. C., Maquaire, O., Martin, B., and Weber, D.: Landslides and climatic conditions in the Barcelonette and Vars basins (Southern French Alps, France), Geomorphology, 30, 65-78, 1999.

Gambi, L.: Le regioni d'Italia, Calabria, Vol. 16, Utet, Torino, 1978.

Glade, T.: Landslide hazard assessment and historical landslide data - an inseparable couple?, in: The use of historical data in natural hazard assessments, edited by: Glade, T., Albini, P., and 
Frances, F., Advances of Technological and Natural Hazard Research, Kluwer, 153-169, 2001.

Glaser, R. and Stangl, H.: Historical floods in the Dutch Rhine Delta, Nat. Hazards Earth Syst. Sci., 3, 605-613, 2003, http://www.nat-hazards-earth-syst-sci.net/3/605/2003/.

Guerricchio, A. and Melidoro, G.: Ricerche di geologia applicata all'archeologia della città di Sibari sepolta, Geologia Applicata e Idrogeologia, 10/I, 107-128, Bari, Italy, 1975.

Guerricchio, A. and Ronconi, M. L.: Osservazioni geomorfologiche nella Piana di Sibari e variazioni delle linee di costa storiche nella zona degli scavi archeologici, I quaderni IRFEA, 5, 12, Cassano Ionio (CS), Italy, 4-29, 1997.

Guidoboni, E.: Dati di base e metodo di indagine: una navigazione fra effetti sismici e contesti storici, Istituto Nazionale di Geofisica e SGA Storia Geofisica Ambiente, Bologna, Italy, 20-57, 1995.

Guzzetti, F.: Landslide fatalities and the evaluation of landslide risk in Italy, Eng. Geol., 58, 89-107, 2000.

Hosking, J. R. M.: The theory of probability-weighted moments, IBM Math. Research Report RC12210, Yorktown Heights, New York, 1986.

Ibsen, M. L. and Brunsden, D.: The nature, use and problems of historical archives for the temporal occurrence of landslides, with specific reference to the South coast of Britain, Ventnor, Isle of Wight, Geomorphology, 15, 241-258, 1996.

Jenkinson, A. F.: The frequency distribution of the annual maximum (or minimum) values of meteorological elements, Q. J. Roy. Meteor. Soc., 81, 158-171, 1955.

Lambeck, K., Antonioli, F., Purcell, A., and Silenzi, S.: Sea-level change along the Italian coast for the past 10,000 yr, Quatern. Sci. Rev., 23, 1567-1598, 2004.

Liguori, F.: Grecia e Magna Grecia, Il cammino degli Dei, Itinerario storico, Roma, Italy, 2000.

Medici, G. and Principi, P.: Le bonifiche di S. Eufemia e di Rosarno, Zanichelli, Bologna, Italy, 1939.

Medici, G.: I consorzi di bonifica e i loro attuali problemi, Staderini, Roma, Italy, 1954.

Mendicino, G. and Versace, P.: Space-Time Analysis of Water Deficit. 5th International Conference "Water Resources Management in the Era of Transition", Athens, 36-43, 2002.

Petrucci, O. and Versace, P.: ASICal: a database of landslides and floods occurred in Calabria (Italy), Proc. 1st Italian-Russian Workshop: New Trends in Hydrology, CNR-GNDCI N. 2823, Bios, Cosenza, Italy, database available at: http://www.camilab. unical.it, 2004.

Petrucci, O. and Versace, P.: Frane e alluvioni in provincia di Cosenza agli inizi del '900: ricerche storiche nella documentazione del Genio Civile, Bios, Cosenza, Italy, 2005.

Placanica, A.: I caratteri originali, Storia d'Italia, le regioni dall'Unità ad oggi: La Calabria, Einaudi, Torino, Italy, 1985.
Polemio, M. and Casarano, D.: Rainfall and drought in southern Italy (1821-2001), The Basis of Civilization, Water Science, IAHS Publ. 286, 217-227, 2004.

Polemio, M. and Petrucci, O.: The drought and the lowering of groundwater resources: an example from Calabria region (Southern Italy), International Conference "Hydrology of the Mediterranean and semi arid regions", Montpellier, 1-6, 2003.

Regione Calabria, Autorità di Bacino: Piano stralcio per l'assetto idrogeologico della Calabria, http: //www.autoritadibacinocalabria.it, 2001.

Ricci-Lucchi, F., Colella, A., Gabbianelli, G., Rossi, S., and Normark, W. R.: Crati Fan, Mediterranean, in: Submarine Fans and Related Turbidite Systems, edited by: Bouma, A. H., Normark W. R., and Barnes, N. E., Springer-Verlag, New York, 51-57, 1985.

Rother, K.: Agrarian development and conflicts of land utilization in the coastal plains of Calabria (South Italy), Geo Journal, D. Reidel Publishing Company, 13.1, 27-35, 1986.

Ruini, M.: Le opere pubbliche in Calabria: introduzione. Prima relazione sull'applicazione delle Leggi Speciali dal 30 giugno 1906 al 30 giugno 1913, Istituto italiano d'arti grafiche, Bergamo, Italy, 1913.

Sabato, L. and Tropeano, M.: Fiumara: a kind of high hazard river, Phys. Chem. Earth, 29, 707-715, 2004.

Sorriso-Valvo, M.: Geomorfologia del Bacino del Crati. Ambiente Crati '91: Club Trekking Val Calamo, Amministrazione Provinciale di Cosenza, Assoc. Naz. Turismo Equestre, Cosenza, Italy, 1991.

Sorriso-Valvo, M. and Tansi, C.: Carta delle grandi frane e delle deformazioni gravitative profonde di versante della Calabria, CNRGruppo D.G.P.V., SELCA, Firenze, Italy, 1995.

Veltri, P. and Fiorini Morosini, A.: Archivio delle coste calabresi e stima del rischio di erosione costiera tramite un metodo parametrico. Memorie e studi del Dipartimento di Difesa del Suolo, Università degli Studi della Calabria, 372, 2003.

Versace, P., Ferrari, E., Gabriele, S., and Rossi, F.: Valutazione delle piene in Calabria. CNR-IRPI, Geodata N. 30, Cosenza, Italy, 1989.

Vezzani, L.: I terreni plio-pleistocenici del basso Crati (Cosenza), Atti della Accademia Gioenia di Scienze Naturali in Catania, Serie VI, XX, 28-84, 1968.

Viparelli, M.: La sistemazione delle aste terminali delle fiumare calabre. Università di Napoli, Istituti Idraulici, Pubbl. N. 276, Napoli, Italy, 1972.

Zecchi, R., Giorni, G., Francavilla, F. and Ronchi, A.: Tendenze evolutive recenti del delta del fiume Crati (Calabria - Italy) sulla base della cartografia storica e delle immagini telerilevate, Atti VII Conf. Naz. ASITA, Verona, Italy, 2, 1885-1890, 2003. 